\title{
Cultural Rights and Cultural Identity in the Case-Law of the Human Rights Committee
}

\section{Introduction}

For decades cultural rights have been a neglected category of human rights. ${ }^{1}$ Although some of the international human rights treaties provide for their protection, none of them formulates a comprehensive definition or enumeration. That underdevelopment should be attributed, at least in part, to the vagueness of the term 'culture'. ${ }^{2}$ International legal discourse defines culture in three different contexts. The first one, connected with international trade, sees it as a type of commercial product, the second as an effect of human practice in the fields of art, music or literature. According to the third one, influenced mostly by anthropologists and sociologists, culture constitutes a specific way of life of a given group of people. ${ }^{3}$ In this article I refer to the last understanding of culture - as the totality of ideas, customs, traditions, distinctive beliefs and practices of specific groups. This understanding is in accordance with the definition developed in the UNESCO Universal Declaration on Cultural Diversity, which states: "culture should be regarded as the set of distinctive spiritual, material, intellectual and emotional features of society or a social group [...] it encompasses, in addition to art and literature, lifestyles, ways of living together, value systems, traditions and beliefs." 4

1 J. Symonides, Cultural rights: a neglected category of human rights, "International Social Science Journal" 1998, vol. 50, no. 158, pp. 559-572.

2 Ibidem, p. 560.

3 M. al Attar, N. Aylwin, R.J. Coombe, Indigenous Cultural Heritage Rights in International Human Rights Law, in Protection of First Nations Cultural Heritage: Laws, Policy, and Reform, ed. C. Bell, R. K. Paterson, Vancouver - Toronto 2009, pp.330-331. See also the three understandings of the term culture formulated in R. Williams, Keywords. A vocabulary of culture and society, New York 1985, pp. 87-93.

4 UNESCO Universal Declaration on Cultural Diversity, 2 November 2001, Resolution of the $31^{\text {st }}$ General Conference of UNESCO. A similar definition had been already formulated by a Mexico City Declaration on Cultural policies, according to which culture is "the whole complex of distinctive spiritual, material, intellectual and emotional features that characterize 
It should be no surprise that the majority of claims concerning cultural rights come from vulnerable groups, i.e. minorities and indigenous people. That tendency shows that they are the most threatened by infringements in that field. The first significant examples of the imposition of a 'cultural hegemony' date back to colonial times. It was then that indigenous communities became outnumbered by the influx of colonists. One of the undesirable results of the interaction between the indigenous peoples and the descendants of the settlers was the dominance of a hegemonic culture over traditional cultures. It proceeded in conformity with the ideology of supremacy over the conquered communities. As Edward Said rightly pointed out, "almost all colonial schemes begin with an assumption of native backwardness and general inadequacy to be independent, 'equal' and fit." Steps taken in order to seize the lands and resources, involving atrocities and policies of discrimination against indigenous people, have been justified, inter alia, through references to Darwin's theory of evolution, according to which the stronger will always extirpate the weaker. ${ }^{6}$ The author himself observed that "wherever the European has trod, death seems to pursue the aboriginal." ${ }^{7}$ Many years later that fact was acknowledged by the United Nations Declaration on the Rights of Indigenous Peoples, which states: "indigenous peoples have suffered from historic injustices as a result of, inter alia, their colonization and dispossession of their lands, territories and resources, thus preventing them from exercising, in particular, their right to development in accordance with their own needs and interests."

Colonial times are over, but the prejudice against differences persists. To date, the cultures of minorities are at risk mostly due to the States' interference in their ways of life. Above all, that refers to indigenous peoples, who are the most underprivileged group of that category. Originally considered as backward, today perceived as a threat to progress - indigenous peoples are often urged to abandon their lands. This does not necessarily occur through direct dispossession, but rather through the State's undesirable interference in landscapes, which may jeopardise the cultural customs of tribal communities.

a society or social group. It includes not only the arts and letters, but also modes of life, the fundamental rights of the human being, value systems, traditions and beliefs". V. Mexico City Declaration on Cultural Policies, 6 August 1982, adopted during second World Conference on Cultural Policies.

5 E.W. Said, Culture and Imperialism, New York 1993, p. 80.

6 S. Lindqvist, Terra Nullius. Podróż przez ziemię niczyja, Warszawa 2010, pp. 39-41.

7 The same observation was shared by the ethnologist James Prichard, who noted: "Wherever Europeans have settled, their arrival has been the harbinger of extermination to the native tribes." V. A. D. Moses, Genocide and Settler Society, in Australian History in Genocide and Settler Society: Frontier Violence and Stolen Indigenous Children in Australian History, ed. A.D. Moses, New York - Oxford 2004, p. 5.

8 United Nations Declaration on the Rights of Indigenous Peoples, 13 September 2007, A/RES/ 61/295. 
Consequently, the States' efforts have led to a rise in the ethnic consciousness of minorities. ${ }^{9}$ Over time, endeavours to secure the rights of these minorities have acquired a more organised character, such that their voices could be heard in international forums. However, the process leading to a final acknowledgement of minority rights took long a long time. After the Second World War, the international community awoke to the dangers of racial and religious discrimination, but ironically did not recognize the issue of minority protection as a distinctive problem. Thanks to the UN Charter, the rights of minorities were confined to the human rights framework and for a long time realized in line with the principle of non-discrimination. ${ }^{10}$ Undoubtedly, the problem of minority protection was marginalized due to post-war struggles for political stability and the territorial integrity of States. 'Positive protection' of minorities was finally possible thanks to the International Covenant on Civil and Political Rights ${ }^{11}$ (henceforth referred to as 'the Covenant' or ICCPR) - the first internationally binding document that includes a provision specifically referring to minority rights. Article 27 of the Covenant reads as follows, "In those States in which ethnic, religious or linguistic minorities exist persons belonging to such minorities shall not be denied the right, in community with the other members of their group, to enjoy their own culture, to profess and practise their own religion, or to use their own language".

In other words, minorities are granted the right to live as they choose - in accordance with their own traditions, customs and beliefs. All these rights fall under the notion of the so-called 'right to cultural identity' - a term commonly used in soft law instruments, and international legal discourse, but overlooked by legally binding instruments under international law. The notion cultural identity, appears in General Comment no. 23 on The Rights of Minorities, although without further elaboration. Interpreting the provisions of Article 27, the Human Rights Committee has found that "[...] the protection of these rights is directed towards ensuring the survival and continued development of the cultural, religious and social identity of the minorities concerned, thus enriching the fabric of society as a whole." 12 To better understand the concept of cultural identity, it seems reasonable to refer to General Comment no. 21 on the Right of Everyone to Take Part in Cultural Life, which provides a more detailed elaboration. The document reads

9 R.G. Buendia, Ethnic Identity, Self-Determination and Human Rights: A Re-Examination of Majoritarian Democracy, "Kasarinlan. Philippine Journal of Third World Studies" 1993, vol. 8, no. 4: The NDF at 20: A Front United?, p. 83.

10 A.F. Vrdoljak, Minorities, Cultural Rights and the Protection of Intangible Cultural Heritage, paper presented at the ESIL (European Society for International Law) Research Forum on International Law, Conference on Contemporary Issues, 26-29 May 2005.

11 International Covenant on Civil and Political Rights, 19 December 1966, A/RES/21/2200.

12 Human Rights Committee, General Comment no. 23: The Rights of Minorities (Article 27), 8 April 1994, Doc. CCPR/C/21/Rev.1/Add.5. 
as follows: "[...] minorities have the right to their cultural diversity, traditions, customs, religion, forms of education, languages, communication media (press, radio, television, Internet) and other manifestations of their cultural identity and membership." 13 Therefore, the statement that culture "encompasses all manifestations of human existence"14 appears justified. Further detailing of the cultural rights of minorities can be attributed to the Declaration on the Rights of Persons Belonging to National or Ethnic, Religious and Linguistic Minorities, ${ }^{15}$ which was inspired by the provisions of Article 27 of the ICCPR. Article 1(1) of the document reads, "States shall protect the existence and the national or ethnic, cultural, religious and linguistic identity of minorities within their respective territories and shall encourage conditions for the promotion of that identity".

Interestingly, scientific discourse provides various justifications for the need to secure cultural identity. Some people recognize a close link between culture and sovereignty, and argue that cultural identity constitutes the essential element. ${ }^{16}$ There are also those putting forward even more daring opinions - that genocide occurs through the destruction of cultural identity. ${ }^{17}$ According to the most common view, the individual's personality is realized through his/her culture, hence, to respect a person, it is vital to give due consideration to all manifestations of his/her cultural identity, including ways of life, religion and language.

After the ICCPR came into force, the struggle for cultural identity may be reflected in recourse to procedures available under the auspices of the United Nations. Through the complaint procedure of the Human Rights Committee, individuals may bring cases against States that have ratified the aforementioned International Covenant on Civil and Political Rights and its Optional Protocol. ${ }^{18}$ In light of the collective char-

13 Committee on Economic, Social and Cultural Rights, General Comment no. 21: Right of Everyone to Take Part in Cultural Life (Article 15, § 1 (a)), 21 December 2009, Doc. E/C.12/ $\mathrm{GC} / 21, \S 32$.

14 Ibidem, § 11 .

15 Declaration on the Rights of Persons Belonging to National or Ethnic, Religious and Linguistic Minorities, 18 December 1992, A/RES/47/135.

16 According to V.J. Deloria indigenous sovereignty "consists more of a continued cultural integrity than of political powers and to that degree that a nation loses its sense of cultural identity, to that degree it suffers a loss of sovereignty." Cited from: S. Wiessner, The Cultural Rights of Indigenous Peoples: Achievements and Continuing Challenges, "The European Journal of International Law"2011, no. 22, p. 129.

17 K. Anderson, Colonialism and Cold Genocide: The Case of West Papua, "Genocide Studies and Prevention: An International Journal” 2015, no. 9: Time, Movement, and Space: Genocide Studies and Indigenous Peoples, p. 16. "Yet, where cultural genocide is linked inextricably to physical genocide, acts that may be characterised as cultural genocide should in fact be plainly considered genocide."

18 The Human Rights Committee exercises control over the implementation of the International Covenant on Civil and Political Rights by its state parties by means of different types of procedures. The first one - periodic reporting - involves State's obligation to submit reports on how 
acter of the rights falling under the notion of the right to cultural identity, they act as the "representatives" and peculiar "guards" of values pertaining to the community they belong to. ${ }^{19}$

So far, Article 27 of the Covenant has been invoked forty times in the aforementioned procedure before the Human Rights Committee. The complaints were based on various grounds: ranging from interference with ancestral lands (as invoked by the Sami people against Finland, Norway and Sweden; the Aymara people against Peru; or the indigenous community of Maori against New Zealand), restrictions on the right to profess and practise one's own religion, to infringements of the right to use a minority language (brought most commonly by Bretons against France). The Committee has, so far, adopted views relating to twenty-seven individual communications, deciding on the inadmissibility of the others. Nearly half of these cases have been brought before the Committee by indigenous communities claiming to be victims of the violation of the right of individuals to enjoy their own culture together with the other members of the group. The examples presented below demonstrate that steps taken by the State in the name of economic development might have an undesirable impact on territories, and may hamper the execution of cultural rights pertaining to those distinct communities. That issue is addressed at the beginning of this article, with specific regard given to the concept of land in indigenous peoples' cultures. Then, I focus on the subject of respect for the right to profess and practice a minority religion. Despite the scarcity of the Committee's jurisprudential elaboration in that field, it can be undeniably stated that respect for this right is vital for the full realisation of the right to cultural identity. So is, of course, the right to use a minority language, which is addressed in the subsequent part of the article. Last but not least, the study aims to present the phenomenon of ethnocide, and tries to answer whether this still poses a danger for minority cultures.

the rights are being implemented. Possible concerns and recommendations of the Committee are voiced in so-called 'concluding observations.' Thanks to the publication of Committee's findings public attention focuses on a country under review. The complaints procedure, on the other hand, enables individuals to bring cases against States that have ratified the Covenant and its Optional Protocol.

19 F. Lanzerini, Indigenous Peoples' Cultural Rights and the Controversy over Commercial Use of their Traditional Knowledge, in Cultural Human Rights, ed. F. Francioni, M. Scheinin, Leiden - Boston 2008, pp. 125-126. A. Jakubowski refers to minorities and indigenous peoples as specific categories of collective cultural rights holders, A. Jakubowski, Introduction, in Cultural Rights as Collective Rights: An International Law Perspective, ed. A. Jakubowski, Leiden 2016, p. 7. For an elaboration on cultural rights as a collective entitlement also: K. Hossain, Protection of Community Culture as Part of Human Rights in International Law, in Cultural Rights..., op. cit., pp. 113-132. 


\section{The right to enjoy one's own culture in the case-law of Human Rights Committee}

\section{Land as the Foundation of Indigenous Cultures}

One of the characteristics that best describes those culturally distinct identities is their strong relationship with the land and dependence on natural resources as the means of livelihood. Their modes of production, and consequently ways of life, are being adjusted to environmental conditions. They are even called, "ecosystem people" by some authors since they constitute an intrinsic part of the ecosystem. ${ }^{20}$ That distinctive feature of the indigenous peoples was also recognized in the UNESCO Declaration of San Jose, adopted on the wave of protests against the loss of cultural identity among the Indian populations of Latin America:

"For the Indian peoples, the land is not only an object of possession and production. It forms the basis of their existence, both physical and spiritual, as an independent entity. Territorial space is the foundation and source of their relationship with the universe and the mainstay of their view of the world."21

A spiritual attitude towards land and natural resources characterizes many culturally distinct entities. For instance, the Quichua ${ }^{22}$ believe that spirits living within mountains, hills and rivers exercise control over plants and animals. ${ }^{23}$ The Massai people perceive land as God-given and therefore belonging to the entire community. They worship Mother Earth as a source of spirituality for human lives. ${ }^{24}$ In the Samburu's culture, land and the environment are even subjects of songs, which praise their importance for all generations. ${ }^{25}$ For tribal Filipinos, the land, as a source of life, is owned by God, however, people as 'secondary owners', have the right to exploit it. They emphasise that there is an inseparable bond between land ownership and a people's identity. ${ }^{26}$ Being completely

20 P.L. Bennagan, Tribal Filipinos, in Indigenous Views of Land and the Environment, ed. S.H. Davis, World Bank Discussion Paper no.188, Washington DC 1993, p. 67.

21 UNESCO Declaration of San Jose, 11 December 1981, UNESCO Doc. FS 82/WF.32 (1982).

22 The largest Indian group of indigenous peoples in the Ecuadorian Amazon.

23 S. H. Davis, Introduction, in Indigenous Views..., op. cit., p. 14.

24 K. Matampash, The Massai of Kenya, in Indigenous Views..., op. cit., pp. 32, 35-36.

25 G. Lochgan, The Samburu of Kenya, in Indigenous Views..., op. cit., pp. 46-47. One of the Samburu dwellings goes: "Your father will be telling you when you look after cows, 'this day go through here, now take this route' and you will slowly learn why he is telling you that. When you become a moran you will be allowed to attend elders meetings when they discuss and decide; 'all families would move to this or the other side, 'all cows should be driven to some place for this period because we want this land to recover here." Ibidem, pp. 46-47.

26 P.L. Bennagan, op. cit., pp. 68-70. Part of the summary of responses obtained during the consultation conducted in Mindanao (1985) by the Episcopal Commission on Tribal Filipinos of the Roman Catholic Church reads: "land is also seen as a symbol of identity. It symbolizes their historical identity because they see it as an ancestral heritage that is to be defended and preserved for all future generations. It symbolizes their local identity because they believe that 
dependent on the environment, indigenous peoples developed specific systems to protect it. Interestingly, many of the land management practices involve various religious rites, exercised in order to placate spirits responsible for the natural world. ${ }^{27}$ Since some of them constitute a tradition handed down from parents to children, they have remained essentially unchanged to this day. The concept of land ownership has also remained constant. Since the land belongs to God, people are only trustees. Undoubtedly, the strong bond between indigenous peoples and their ancestral lands constitutes an essential part of their identity. Therefore, external influences that have an undesirable impact on their landscapes may hamper the execution of basic rights pertaining to them. Consequently, some of the State's measures that were undertaken in order to promote economic development and which involved a significant interference with the environment have been have been deemed to be in violation of Article 27 of the International Covenant on Civil and Political Rights. ${ }^{28}$ Judicial elaboration of the Committee helps to answer the question on how to define the culture of a minority group and what roles economic activities play in that culture.

\section{Indigenous cultural rights before the Human Rights Committee}

According to the Committee, the right to enjoy one's own culture is very closely related to the right to engage in economic and social activities that are part of the culture of a distinct community. Analysis of the Human Rights Committee's jurisprudence shows that there is a wide range of such activities. ${ }^{29}$

For instance, in the most recent case, Angela Poma Poma v. Peru, ${ }^{30}$ the Committee dealt with a complaint brought by a member of an ethnic minority called the Aymara. The activity that took center stage in the Committee's examinations was the raising of

wherever they are born, there too shall they die and be buried, and their own graves are proof of their rightful ownership of the land. It symbolizes their tribal identity because it stands for their unity, and if the land is lost, the tribe, too, shall be lost." Ibidem, p. 69.

27 Ibidem, p. 75.

28 The significant influence of modernization on the cultural identities of distinct communities was very appropriately recognized by R. G. Buendia, who stated: "while it is commonly argued that for economic growth and development to take place, certain cultural identities have to be compromised and undermined for the interest of the majority, these culturally homogenizing, socially fragmenting, and atomizing processes of modernization bring in conditions of social and economic vulnerability and insecurity to ethnic groups." V. R. G. Buendia, op. cit., p. 83.

29 In order to establish what kinds of economic and social activities constitute a part of minorities' culture the Committee carries out a peculiar 'cultural test.' V. J. Gilbert, Nomadic Peoples and Human Rights, London - New York 2014, pp. 177-178.

30 Human Rights Committee, Ángela Poma Poma v. Peru, Communication no. 1457/2006, UN Doc. CCPR/C/95/D/1457/2006. 
livestock, principally alpacas and llamas, which form the basis of the Aymara's economy and culture. Until the Government of Peru significantly interfered in the landscape, it was the only means of survival for the author and her family. The State's actions were aimed at the diversion of water from the Andes to the Pacific coast in order to provide water for the city of Tacna. The community did not manage to forestall the implementation of the project and, as a consequence of the diversion of the river and well-drilling carried on over many years, animals were deprived of water, which lead to the death of a great deal of livestock.

The author of the complaint alleged that the State's actions constituted a violation of Article $1 \S 2^{31}$ of the International Covenant on Civil and Political Rights, by depriving her of her livelihood, and of Article 1732, by interference in her family's life and activities, since, as she rightly stipulated "[...] private and family life consists of their customs, social relations, the Aymara language and methods of grazing and caring for animals. This has all been affected by the diversion of water." Having examined the presented facts, the Committee found that they rather raised issues related to Article 27 of the Covenant, and declared the communication admissible in respect of the complaints under its provisions. ${ }^{33}$

The Committee observed that the steps taken by the State in order to promote economic development should comply with the proportionality principle. ${ }^{34}$ It also found that prior participation of a specific community in the decision-making process may legitimatize the State's measures. ${ }^{35}$ Since, in this case no consultations were held with the community, no studies were carried out in order to assess the possible impact of the undertaken measures on the traditional activities of the Aymara people, nor were any actions applied in order to minimize the negative consequences, the Committee found that the State's activities violated the author's right to enjoy her own culture together with the other members of her group, in accordance with Article 27 of the Covenant. The finding

31 "2. All peoples may, for their own ends, freely dispose of their natural wealth and resources without prejudice to any obligations arising out of international economic co-operation, based upon the principle of mutual benefit, and international law. In no case may a people be deprived of its own means of subsistence."

32 "1. No one shall be subjected to arbitrary or unlawful interference with his privacy, family, home or correspondence, nor to unlawful attacks on his honour and reputation."

33 Ángela Poma Poma v. Peru, § 6.5.

34 "Economic development may not undermine the rights protected by Article 27. Thus the leeway the State has in this area should be commensurate with the obligations it must assume under Article 27." Ibidem, § 7.4.

35 "In the Committee's view, the admissibility of measures which substantially compromise or interfere with the culturally significant economic activities of a minority or indigenous community depends on whether the members of the community in question have had the opportunity to participate in the decision-making process in relation to these measures and whether they will continue to benefit from their traditional economy." Ibidem, § 7.6. 
confirmed - as had already been stated in the aforementioned General Comment No. 23 on The Rights of Minorities, which clarifies the provisions of Article $27 \mathrm{ICCPR}$ - that the right to enjoy one's culture may be manifested in a particular way of life. ${ }^{36}$

It also followed some previous verdicts concerning the measures of States which pose a threat to the cultures of minorities. Many of them involved the complaints of the Sami people brought against Finland, Norway, and Sweden. For instance in Ivan Kitok v. Sweden, ${ }^{37}$ the author of the complaint claimed that, as a result of government's legislation (Reindeer Husbandry Act of 1971), ${ }^{38}$ he was denied his “inherited 'civil right' to reindeer breeding" and argued that it was equal to preventing the exercise of the right to enjoy the culture of the Sami. The Committee acknowledged the importance of reindeer husbandry for the Sami community and found that "the regulation of an economic activity is normally a matter for the State alone. However, where that activity is an essential element in the culture of an ethnic community, its application to an individual may fall under Article 27 of the Covenant." ${ }^{39}$

In Länsman et al. v. Finland ${ }^{40}$ reindeer breeding activity also took center stage in the Committee's examinations. This case dealt with a complaint concerning the process of stone quarrying, which had an impact on reindeer herding in traditional Sami lands. Although the Committee did not find a breach of Article 27 (the State met the requirement of the consultation voiced in Comment no. 23), it conceded that reindeer

36 "With regard to the exercise of the cultural rights protected under Article 27, the Committee observes that culture manifests itself in many forms, including a particular way of life associated with the use of land resources, especially in the case of indigenous peoples. That right may include such traditional activities as fishing or hunting and the right to live in reserves protected by law." V. Human Rights Committee, General Comment no. 23: The Rights of Minorities (Article 27), § 7.

37 The Human Rights Committee, Ivan Kitok v. Sweden, Communication no. 197/1985, UN Doc. $\mathrm{CCPR} / \mathrm{C} / 33 / \mathrm{D} / 197 / 1985$.

38 According to the State, the ratio legis of the Reindeer Husbandry Act was to secure the wellbeing of the Sami, who occupy in reindeer husbandry. In practice, however, it restricted the number of reindeer breeders and provided for rearrangements in existing Sami villages - under new legislation they were reorganized into larger units. Substantial changes in that field have resulted in huge interference in the social structures of the Sami community, since "the Sami villages have their origin in the old siida, which originally formed the base of the Sami society consisting of a community of families which migrated seasonally from one hunting, fishing and trapping area to another, and which later on came to work with and follow a particular selfcontained herd of reindeer from one seasonal grazing area to another." Ibidem, § 4.2. What is more, Swedish legislation granted the Sami population the power to decide on issues of membership in Sami villages, causing the division of the Sami community into reindeer-herding (full Sami) and non-reindeer herding (half-Sami). It resulted in difficulties in maintaining the Sami identity for the latter group.

39 Ibidem, § 9.2.

40 Human Rights Committee, Länsman et al. v. Finland, Communication no. 511/1992, UN Doc. $\mathrm{CCPR} / \mathrm{C} / 52 \mathrm{D} / 511 / 1992$. 
husbandry constitutes a traditional activity which deserves protection. In the second Länsman case brought before it, the Committee assessed the impact of logging and the construction of roads on such traditional economic practices. ${ }^{41}$

In Lubicon Lake Band v. Canada ${ }^{42}$, on the other hand, the Committee ruled that Canada had violated minority rights under Article 27, by allowing the provincial government of Alberta to expropriate the land of Lubicon Lake Band for private corporate interests (such as leases for oil and gas exploration) notwithstanding prior arrangements granting the original inhabitants of that area the right to continue their traditional way of life.

Similarly, in Apirana Mahuika et al. v. New Zealand ${ }^{43}$ the Committee examined the complaint submitted by individuals belonging to the Maori people of New Zealand. Due to a dramatic growth in the fishing industry, the government decided to implement a mechanism for the conservation of New Zealand's fisheries resources and to regulate commercial fishing. The adoption of new measures provided in the Treaty of Waitangi (Fisheries Claims) Settlement Act had an unintended negative impact on Maori fishers. Since fishing constitutes an essential element of traditional Maori culture, they maintained that the State's actions threatened both their ways of life and culture. What is more, the authors claimed that they were denied the right to determine their political status, as the right to self-determination can be exercised only with full access to, and control over, resources. ${ }^{44}$ In this case, the Committee did not find the State party in violation of Article 27, mostly because of its engagement in the consultation process, during which the cultural and religious significance of fishing for the Maori was acknowledged. ${ }^{45}$ However, it emphasised that any steps that may affect the economic activities of the Maori must be taken in a way that ensures the authors' right to enjoy their culture, and profess and practice their religion in a community with other members of their group. ${ }^{46}$

Judicial elaboration confirms an undoubted and strong bond between indigenous peoples' cultures and land rights. Economic activities which constitute an essential element of the culture of a community may fall within the ambit of the right to enjoy one's own culture. Therefore, the right to preserve their distinct identity involves, above all, the possibility to continue their inherited ways of life. Dispossessing a community of

41 Human Rights Committee, Länsman et al. v. Finland, Communication no. 671/1995, UN Doc. CCPR/C/58/D/671/1995.

42 Human Rights Committee, Lubicon Lake Band v. Canada, Communication no. 167/1984, UN Doc. CCPR/C/38/D/167/1984

43 Human Rights Committee, Apirana Mahuika et al. v. New Zealand, Communication no. 547/1993, UN Doc. CCPR/C/70/D/547/1993.

44 Ibidem, § 6.1 .

45 Ibidem, §§ 9.5, 9.6, 9.8.

46 Ibidem, § 9.9. 
its economic livelihood may, under certain circumstances, be equal to robbing it of its cultural identity. ${ }^{47} \mathrm{It}$, therefore, has an impact going far beyond financial consequences.

Indigenous peoples' rights of ownership and possession over the land and its natural resources are commonly recognized by international law. ${ }^{48}$ Unfortunately, however, such cases of resistance to state-proposed projects involving interference with ancestral lands and unceasing struggles for a respect for indigenous customs and ways of life prove the continuing relevance of the problem. A statement made in 1989 by Morinage Parkipuny remains true to date. Before the United Nations Working Group on Indigenous Populations he said: "the process of alienation of our land and its resources was launched by European colonial authorities at the beginning of this century and has been carried on, to date, after the attainment of national independence." ${ }^{49}$

\section{The right to profess and practise a minority religion}

The Committee has twice dealt with complaints invoking an infringement of Article 27 in the context of a minority's right to profess and practice their own religion. In neither of them, however, was a violation found. For instance, in the case Prince v. South Africa ${ }^{50}$ the author of the complaint, who was a Rastafarian, i.e. a member of a religious minority group in South Africa, claimed that the State had infringed his rights by prohibiting the possession and use of cannabis. ${ }^{51}$ Gareth Anver Prince was a law graduate and wanted to become an attorney. Having fulfilled all the academic requirements, he had to perform a period of community service before being allowed to practice. He filed an application to the relevant body (the Law Society of Cape of Good Hope) to register his contract of community service but was refused due to his prior convictions for possessing cannabis.

47 "Culture or way of life cannot survive if the bearers of that culture have to change their ways of making a living." V. D. Maybury-Lewis, Indigenous Peoples, Ethnic Groups, and the State, Boston - London - Toronto - Sydney - Tokyo - Singapore 1997, p. 37.

48 V. Articles 13-16 of International Labour Organization Convention (no. 169) concerning Indigenous and Tribal Peoples in Independent Countries, 27 June 1989, adopted during $76^{\text {th }}$ ILC session and Articles 25-26 of United Nations Declaration on the Rights of Indigenous Peoples.

49 M. Parkipuny, The Human Rights Situation of Indigenous Peoples in Africa, Statement before the Sixth Session of the United Nations Working Group on Indigenous Populations in Genéve, Switzerland on August 3, 1989, "Fourth World Journal" 1989, vol. II, no. 2, http://cwis.org/ FWJ/classic/?issue=117\# [access: 15.01.2017].

50 Human Rights Committee, Prince v. South Africa, Communication no. 1474/2006, UN Doc. CCPR/C/91/D/1474/2006.

51 The Rastafari religion originated in Jamaica. It's roots lie in the black consciousness movement that sought to overthrow colonialism, oppression and domination. The use of cannabis constitutes an inherent element of that religion. Regarded as a "holy herb" it is used at religious gatherings, as well as in private homes. At religious ceremonies, it is smoked through a chalice (water-pipe) as part of Holy Communion, and burnt as incense. However, it is used not only for spiritual, but also for medical and even culinary purposes. Ibidem, $\S 2.1$. 
In other words, the Law Society's assessment was that he was not a "fit and proper" candidate. Before the Committee, he claimed that Rastafarians use and possess cannabis for religious purposes and postulated that they should be granted an exemption from the general prohibition of possession and use of that drug. The Committee acknowledged the fact that the use of cannabis is inherent to the manifestation of the Rastafari religion, but at the same time concluded that the freedom of religion and the right of minorities to profess and practice it freely, as guaranteed in Articles 18 and 27, are not absolute and can be limited in order to protect public safety, order, health, morals, or the fundamental rights and freedoms of others.

In Waldman v. Canada ${ }^{52}$, on the other hand, the Committee had to find whether in light of Ontario's exclusive funding of Roman Catholic schools, ${ }^{53}$ the lack of funding to other religious schools constituted a violation of Articles $26^{54}$ and 27 of the International Covenant on Civil and Political Rights. The author of the complaint, a member of the Jewish faith, pointed out that non-secular schools "form an essential link in preserving community identity and the survival of minority religious groups and that positive action may be required to ensure that the rights of religious minorities are protected." 55 The Committee acknowledged differential treatment between the Roman Catholic faith and the author's religious denomination in the field of educational funding, and found the State party in breach of Article 26. ${ }^{56}$ Unfortunately, however, it did not address the issue of the infringement of Article 27. ${ }^{57}$

52 Human Rights Committee, Waldman v. Canada, Communication no. 694/1996, UN Doc. CCPR/C/67/D/694/1996.

53 The Canadian Constitution Act (1867) provides for exclusive jurisdiction of each province in Canada to enact acts regarding education. In Ontario that power is exercised through the Education Act, under which only Roman Catholic schools are entitled to public funding on equal terms with public secular schools. Ibidem, § 2.3.

54 "All persons are equal before the law and are entitled without any discrimination to the equal protection of the law. In this respect, the law shall prohibit any discrimination and guarantee to all persons equal and effective protection against discrimination on any ground such as race, colour, sex, language, religion, political or other opinion, national or social origin, property, birth or other status".

55 Waldman v. Canada, § 3.5.

56 "The Covenant does not oblige States parties to fund schools which are established on a religious basis. However, if a State party chooses to provide public funding to religious schools, it should make this funding available without discrimination. This means that providing funding for the schools of one religious group and not for another must be based on reasonable and objective criteria. In the instant case, the Committee concludes that the material before it does not show that the differential treatment between the Roman Catholic faith and the author's religious denomination is based on such criteria. Consequently, there has been a violation of the author's rights under article 26 of the Covenant to equal and effective protection against discrimination”. Ibidem, $\S 10.6$.

57 Although a member, Martin Scheinin concurred with the finding, in his individual opinion, he pointed out that "the existence of public Roman Catholic schools in Ontario is related to 


\section{The right to use a minority language}

Last, but not least, the Committee deals with complaints of minorities claiming to be deprived of their right to use their own language. Interestingly, almost a half of these cases were filed by French citizens born in Bretagne who claimed the right to use Breton, which is their mother tongue.$^{58}$ In none of them, however, was the infringement of Article 27 stated. The violation of this Article in the context of language rights was noted in the case of Rakbim Mavlonov and Shansiy Sa'di v. Uzbekistan. ${ }^{59}$ The complaint concerned a denial of re-registration of a newspaper published in a minority language by the State party's authorities. The authors of the communication (both Uzbek citizens of Tajik origin) claimed that they had fallen victims to violations of Article $19^{60}$ and Article 27, read together with Article 2, of the International Covenant on Civil and Political Rights. The articles of "Oina" were published almost exclusively in the Tajik language and concerned education or cultural matters. ${ }^{61}$ Therefore, the newspaper constituted a unique messenger

a historical arrangement for minority protection and hence needs to be addressed not only under article 26 of the Covenant but also under articles 27 and 18." He found, inter alia, that "article 27 imposes positive obligations for States to promote religious instruction in minority religions.” Ibidem, individual opinion by member Martin Scheinin, §§ 4 and 5.

58 See Human Rights Committee, Yves Cadoret, Hervé Le Bihan v. France, Communication no. 323/1988, U.N. Doc. CCPR/C/41/D/323/1988; Hervé Barzhig v. France, Communication no. 327/1988, UN Doc. CCPR/C/41/D/327/1988; Dominique Guesdon v. France, Communication no. 219/1986, UN Doc. CCPR/C/39/D/219/1986. Actually, none of these cases were examined on the merits with regard to Article 27. The French government filed a "declaration" concerning Article 27 of the Covenant, claiming it was not applicable, since the French Constitution guarantees the equality of all citizens before the law. The Committee treated the declaration as a reservation to Article 27, and as a consequence it lacks jurisdiction over cases concerning the Breton language. Unfortunately, such a declaration amounts to a denial of the existence of minority groups in the country.

59 Human Rights Committee, Rakbim Mavlanov and Shansiy Sa'di v. Uzbekistan, Communication no. 1334/2004, UN Doc. CCPR/C/95/D/1334/2004.

60 "1. Everyone shall have the right to hold opinions without interference. 2. Everyone shall have the right to freedom of expression; this right shall include freedom to seek, receive and impart information and ideas of all kinds, regardless of frontiers, either orally, in writing or in print, in the form of art, or through any other media of his choice. 3. The exercise of the rights provided for in paragraph 2 of this article carries with it special duties and responsibilities. It may therefore be subject to certain restrictions, but these shall only be such as are provided by law and are necessary: (a) For respect of the rights or reputations of others; (b) For the protection of national security or of public order (ordre public), or of public health or morals."

61 The Committee adhered to the author's claim that 'Oina' published articles containing educational and other materials for Tajik students and young persons on events and matters of cultural interest to this readership, as well as reported on the particular difficulties facing the continued provision of education to Tajik youth in their own language, including shortages in Tajik-language textbooks, low wages for teachers and the forced opening of Uzbek-language classes in some Tajik schools. See Rakbim Mavlanov and Shansiy Sa'di v. Uzbekistan, § 8.7 
of Tajik's culture to its readers. Problems appeared when, as a consequence of one of the founders' opt-out, the newspaper had to apply for re-registration. The authorities refused to re-register the newspaper due to an alleged violation of the Law "On Mass Media." ${ }^{62}$

Most importantly, in light of the issues addressed in this article, the Committee's verdict proved that culture manifests itself in many forms and the right to enjoy it freely may also involve access to minority language press. In the analysed case, the Committee found that: "[...] the use of a minority language press as means of airing issues of significance and importance to the Tajik minority community in Uzbekistan, by both editors and readers, is an essential element of the Tajik minority's culture." ${ }^{63}$ In other words, the Committee acknowledged the important role of language in defining cultural identity, since it constitutes one of the representatives of the distinct characteristics of a community. Consequently, it fosters the sense of belonging to a certain group. A further detailing of the minorities' language rights can be attributed to the Declaration on the Rights of Persons belonging to National or Ethnic, Religious and Linguistic Minorities, which in Article 4(3) reads: "States should take appropriate measures so that, wherever possible, persons belonging to minorities may have adequate opportunities to learn their mother tongue or to have instruction in their mother tongue." A strong relationship between language and culture was also stressed by the famous linguist, Ken Hale, who lamented: "When you lose a language, you lose a culture, intellectual wealth, a work of art. It's like dropping a bomb on a museum, the Louvre. ${ }^{\prime 4}$

\section{Ethnocide in international legal discourse}

The very term ethnocide appeared for the first time in Lemkin's "Axis Rule in Occupied Europe." When elaborating on the new term and conception for the destruction of nations, Lemkin pointed out that instead of genocide, by which we mean the destruction of a nation or of an ethnic group, the term ethnocide can be used to express the same idea. ${ }^{65}$ Interestingly, in his research Lemkin focused on the cultural elements of the crime: "genocide has two phases: one, destruction of the national pattern of the oppressed group; the other, the imposition of the national pattern of the oppressor." ${ }^{166}$ It

62 According to the commission, the newspaper's work was not performed in accordance with mass media activity towards "enlightment and national ideology building". It accused "Oina" of, inter alia, publishing articles that were inciting inter-ethnic hostility and violating laws prohibiting calls for territorial integrity changes. Ibidem, $\S 2.6$.

63 Ibidem, § 8.7.

64 Cited from: K. D. Harrison, When Languages Die: The Extinction of the World's Languages and the Erosion of Human Knowledge, New York 2007, p. 7.

65 R. Lemkin, Axis Rule in Occupied Europe: Laws of Occupation, Analysis of Government, Proposals for Redress, New Jersey 2005, p. 79.

66 Ibidem. 
appears that according to Lemkin, cultural patterns are as important as the biological structure of a distinct group. Indeed, his objective was to include cultural aspects in the legal definition of genocide. ${ }^{67}$ In his view, the cultural facet of the crime involved a ban on the use of the native language, and upbringing in the spirit of imposed ideology in order to suppress independent national thinking. ${ }^{68}$ However, his postulates were not fully taken into account, and the only cultural aspect included in the final legal definition of the crime of genocide is laid down in Article 2 (e) of the Convention on the Prevention and Punishment of Genocide, and concerns the act of forcibly transferring children of the group to another group. ${ }^{69}$

In the following years, the term ethnocide evolved, and is now more often considered strictly as the policy of destroying other cultures. ${ }^{70}$ Consequently, such practices as exterminating a culture have been called a cultural or passive genocide, although they do not necessarily involve the physical destruction of a group. ${ }^{71}$

In 1981, UNESCO created an international definition of this phenomenon. According to the aforementioned Declaration of San Jose: "ethnocide means that an ethnic group is denied the right to enjoy, develop and transmit its own culture and its own language, whether collectively or individually. This involves an extreme form of massive violation of human rights and, in particular, the right of ethnic groups to respect for their cultural identity [...] ethnocide, that is, cultural genocide, is a violation of international law equivalent to genocide, which was condemned by the United Nations Convention on the Prevention and Punishment of the Crime of Genocide of 1948."

67 For detailed research on the evolution of the term genocide see H. Schreiber, Cultural genocide - ludobójstwo kulturowe - kulturobójstwo: niedokończony czy odrzucony projekt prawa międzynarodowego?, in Kultura w stosunkach międzynarodowych, t. I: Zwrot kulturowy, ed. H. Schreiber, G. Michałowska, Warszawa 2013, pp. 252-274; E. Novic, From 'Genocide' to 'Persecution': 'Cultural Genocide' and Contemporary International Criminal Law, in Cultural Rights..., op. cit., pp. 313-335.

68 R. Lemkin, op. cit., pp. 84-85. In fact, Lemkin distinguished eight different types of genocide (or as he called it: "techniques of genocide in various fields") - political, social, cultural, economic, biological, physical, religious and moral. Ibidem, pp. 82-90.

69 Convention on the Prevention and Punishment of the Crime of Genocide, 9 December 1948, A/RES/3/260.

70 W.A. Schabas, Genocide in International Law: The Crime of Crimes, Cambridge 2000, p. 189; M. Shaw, What is genocide?, Cambridge 2007, pp. 65-67; B. Clavero, Genocide or Ethnocide, 1933-2007. How to make, unmake, and remake law with words, Milan 2008, pp. 99-101.

71 Undoubtedly, however, cultural suppression may precede and herald the crime of genocide and prove the perpetrator's genocidal intent (mens rea). What is more, in the jurisprudence of international criminal tribunals and courts, the link between cultural suppression and persecution, which constitutes one of the acts defining the crime against humanity, was found. Acts directed against cultural heritage are generally perceived as an instrument of repression and an element of the strategy of dehumanisation. For detailed research see S. Stryjkowska, Problematyka ochrony dziedzictwa kulturowego w dziatalności międzynarodowych trybunatów karnych, “Adam Mickiewicz University Law Review” 2016, vol. 6, pp. 222-225. 
In light of the above, it is worth considering whether the problem of ethnocide still threatens native cultures. It is an undisputed fact that minorities throughout the world are being coerced to give up their cultural customs, languages and religious traditions. The foregoing considerations prove that minority cultures at risk mostly due to States' interference in their ways of life, restrictions on the use of their native language, or infringements of the right to practice one's own religion. The cases referred to in this article show that the steps taken by States with regard to minorities may constitute a form of indirect domination, and as a consequence impair the cultural identities of minority communities.

Despite the fact that acts of ethnocide are still being carried out, this subject has not been sufficiently addressed in international law. Admittedly, the prohibition of cultural suppression is enshrined - although not explicitly under the specific name ethnocide - in Article 8(1) of the United Nations Declaration on the Rights of Indigenous Peoples, which states: "indigenous peoples and individuals have the right not to be subjected to forced assimilation or destruction of their culture."The aforementioned declaration is an important instrument aimed at eliminating human rights violations against indigenous peoples, but it does not constitute a legally binding document. Therefore, it is in accordance with the general trend of demonstrating the international community's interest in matters connected with cultural rights through the implementation of the instruments of soft law. Undoubtedly, however, this subject merits more attention, since the observance of cultural rights ensures the perpetuation of distinct groups. ${ }^{72}$

\section{Concluding remarks}

Judicial elaboration proves that a lot has to be done in order to secure desirable, harmonious and cooperative relations between States and minorities. The reservations of States towards minorities can be attributed to the fact that issues of cultural rights pertaining to them, especially the territorial rights of indigenous communities and their entitlement to ancestral lands, are inextricably linked to the concept of self-determination. As culturally distinct entities, they are often considered as a threat to the State's territorial integrity because of their potential wish for secession. In order to avoid this, governments undertake attempts to integrate and assimilate them, frequently violating their basic rights. However, the problem of securing the cultural rights pertaining to them should be treated as a matter of recognition within already existing States. ${ }^{73}$

72 A.F. Vrdoljak, Self-Determination and Cultural Rights, in Cultural Human Rights, op. cit., p. 41.

73 D. Maybury-Lewis, op. cit., p. 56. It has also been stated explicitly in the Human Rights Committee's General Comment no. 23: "the enjoyment of the rights to which article 27 relates does not prejudice the sovereignty and territorial integrity of a State party." V. General Comment no. 23: The Rights of Minorities (Article 27), § 3.2. In the same document the Committee 
It is a truism to say that most existing nations are not culturally homogenous entities. That is why it is so important to create conditions for the amicable coexistence of different cultural traditions. The relevance of cultural diversity is being emphasized by UNESCO, which has advocated for that concept from the very beginning of its existence, since pluralism plays an important role in the organisation's discourse. ${ }^{74}$ According to UNESCO's Universal Declaration on Cultural Diversity "culture takes diverse forms across time and space. This diversity is embodied in the uniqueness and plurality of the identities of the groups and societies making up humankind. As a source of exchange, innovation and creativity, cultural diversity is as necessary for humankind as biodiversity is for nature. In this sense, it is the common heritage of humanity and should be recognized and affirmed for the benefit of present and future generations."

In order to complete the present study, it is worth recalling the view of Anthony Giddens, who argues that racist attitudes in modern societies take the form of 'cultural racism' based on the criteria of cultural differences. ${ }^{75} \mathrm{He}$ stipulates that 'new racism' has already replaced the concept of 'biological racism', since it is more often exercised on cultural rather than biological grounds. ${ }^{76}$ Giddens observes that the values of the majority culture set standards for creating the hierarchy and any reluctance to assimilate with the majority may result in marginalisation. ${ }^{77}$

\section{Literature}

Al Attar M., Aylwin N., Coombe R.J., Indigenous Cultural Heritage Rights in International Human Rights Law, in Protection of First Nations Cultural Heritage: Laws, Policy, and Reform, ed. C. Bell, R. K. Paterson, Vancouver - Toronto 2009.

Anderson K., Colonialism and Cold Genocide: The Case of West Papua, "Genocide Studies and Prevention: An International Journal" 2015, vol. 9.

adopted an interpretation of Article 1 of the Covenant meant to forestall potential claims of autonomy brought before it by minority groups. It stated that an individual cannot claim to be a victim of violation of the right to self-determination enshrined in Article 1 of the Covenant, since it deals with rights conferred upon peoples. "The Covenant draws a distinction between the right to self-determination and the rights protected under article 27 . The former is expressed to be a right belonging to peoples and is dealt with in a separate part (Part I) of the Covenant. Self-determination is not a right cognizable under the Optional Protocol. Article 27 , on the other hand, relates to rights conferred on individuals as such and is included, like the articles relating to other personal rights conferred on individuals, in Part III of the Covenant and is cognizable under the Optional Protocol." Ibidem, § 3.1.

74 J. Tomlinson, Cultural imperialism - A Critical Introduction, London 1991, pp. 70-75.

75 A. Giddens, Sociology, Cambridge - Malden 2006, p. 495.

76 Ibidem.

77 Ibidem. 
136 | Adam Mickiewicz University Law Review

Bennagan P.L., Tribal Filipinos, in Indigenous Views of Land and the Environment, ed. S.H. Davis, World Bank Discussion Paper no. 188, Washington DC 1993.

Buendia R.G., Ethnic Identity, Self-Determination and Human Rights: A Re-Examination of Majoritarian Democracy, "Kasarinlan. Philippine Journal of Third World Studies" 1993, vol. 8, no. 4.

Clavero B., Genocide or Ethnocide, 1933-2007. How to make, unmake, and remake law with words, Milan 2008.

Davis S. H., Introduction, in Indigenous Views of Land and the Environment, ed. S. H. Davis, World Bank Discussion Paper no. 188, Washington DC 1993.

Giddens A., Sociology, Cambridge - Malden 2006.

Gilbert J., Nomadic Peoples and Human Rights, London - New York 2014.

Harrison K. D., When Languages Die: The Extinction of the World's Languages and the Erosion of Human Knowledge, New York 2007.

Hossain K., Protection of Community Culture as Part of Human Rights in International Law, in Cultural Rights as Collective Rights: An International Law Perspective, ed. A. Jakubowski, Leiden 2016.

Jakubowski A., Introduction, in Cultural Rights as Collective Rights: An International Law Perspective, ed. A. Jakubowski, Leiden 2016.

Lanzerini F., Indigenous Peoples' Cultural Rights and the Controversy over Commercial Use of their Traditional Knowledge, in Cultural Human Rights, ed. F. Francioni, M. Scheinin, Leiden - Boston 2008.

Lemkin R., Axis Rule in Occupied Europe: Laws of Occupation, Analysis of Government, Proposals for Redress, New Jersey 2005.

Lindqvist S., Terra Nullius. Podróż przez ziemię niczyją, Warszawa 2010.

Lochgan G., The Samburu of Kenya, in Indigenous Views of Land and the Environment, ed. S.H. Davis, World Bank Discussion Paper no. 188, Washington DC 1993.

Matampash K., The Massai of Kenya in Indigenous Vierws of Land and the Environment, ed. S.H. Davis, World Bank Discussion Paper no. 188, Washington DC 1993.

Maybury-Lewis D., Indigenous Peoples, Ethnic Groups, and the State, Boston - London Toronto - Sydney - Tokyo - Singapore 1997.

Moses A.D., Genocide and Settler Society in Australian History, in Genocide and Settler Society: Frontier Violence and Stolen Indigenous Children in Australian History, ed. A.D. Moses, New York - Oxford 2004.

Novic E., From 'Genocide' to 'Persecution': 'Cultural Genocide' and Contemporary International Criminal Law, in Cultural Rights as Collective Rights: An International Law Perspective, ed. A. Jakubowski, Leiden 2016.

Parkipuny M., The Human Rights Situation of Indigenous Peoples in Africa, Statement before the Sixth Session of the United Nations Working Group on Indigenous Popula- 
tions in Genéve, Switzerland on August 3, 1989, "Fourth World Journal"1989, vol. II, no. 2, http://cwis.org/FWJ/classic/?issue=117\# [access: 15.01 .2017$]$.

Said E.W., Culture and Imperialism, New York 1993.

Schabas W.A., Genocide in International Law: The Crime of Crimes, Cambridge 2000.

Schreiber H., Cultural genocide - ludobójstwo kulturowe-kulturobójstwo: niedokończony czy odrzucony projekt prawa międzynarodowego?, in Kultura w stosunkach międzynarodowych, t. I: Zwrot kulturowy, ed. H. Schreiber, G. Michałowska, Warszawa 2013.

Shaw M., What is genocide?, Cambridge 2007.

Stryjkowska S., Problematyka ochrony dziedzictwa kulturowego w dziatalności międzynarodowych trybunatów karnych, "Adam Mickiewicz University Law Review” 2016, vol. 6.

Symonides J., Cultural rights: a neglected category of human rights, "International Social Science Journal” 1998, vol. 50, no. 158.

Tomlinson J., Cultural imperialism - A Critical Introduction, London 1991.

Vrdoljak A. F., Minorities, Cultural Rights and the Protection of Intangible Cultural Heritage, paper presented at the ESIL (European Society for International Law) Research Forum on International Law, Conference on Contemporary Issues, 26-29 May 2005.

Vrdoljak A.F., Self-Determination and Cultural Rights, in Cultural Human Rights, ed. F. Francioni, M. Scheinin, Leiden - Boston 2008.

Wiessner S., The Cultural Rights of Indigenous Peoples: Achievements and Continuing Challenges, "The European Journal of International Law" 2011, no. 22.

Williams R., Keywords. A vocabulary of culture and society, New York 1985.

Committee on Economic, Social and Cultural Rights, General Comment no. 21: Right of Everyone to Take Part in Cultural Life (Article $15 \S 1$ (a)), 21 December 2009, Doc. $\mathrm{E} / \mathrm{C} .12 / \mathrm{GC} / 21$.

Convention on the Prevention and Punishment of the Crime of Genocide, 9 December 1948, A/RES/3/260.

Declaration on the Rights of Persons Belonging to National or Ethnic, Religious and Linguistic Minorities, 18 December 1992, A/RES/47/135.

Human Rights Committee, General Comment no. 23: The Rights of Minorities (Article 27), 8 April 1994, Doc. CCPR/C/21/Rev.1/Add.5.

Human Rights Committee, Lubicon Lake Band v. Canada, Communication No 167/1984, UN Doc. CCPR/C/38/D/167/1984.

Human Rights Committee, Ivan Kitok v. Sweden, Communication No. 197/1985, UN Doc. CCPR/C/33/D/197/1985.

Human Rights Committee, Dominique Guesdon v. France, Communication No. 219/1986, UN Doc. CCPR/C/39/D/219/1986.

Human Rights Committee, Hervé Barzhig v. France, Communication No. 327/1988, UN Doc. CCPR/C/41/D/327/1988. 
138 | Adam Mickiewicz University Law Review

Human Rights Committee, Yves Cadoret, Hervé Le Bihan v. France, Communication No. 323/1988, U.N. Doc. CCPR/C/41/D/323/1988.

Human Rights Committee, Länsman et al. v. Finland, Communication No. 511/1992, UN Doc. CCPR/C/52D/511/1992.

Human Rights Committee, Apirana Mahuika et al. v. New Zealand, Communication No. 547/1993, UN Doc. CCPR/C/70/D/547/1993.

Human Rights Committee, Länsman et al. v. Finland, Communication No. 671/1995, UN Doc. CCPR/C/58/D/671/1995.

Human Rights Committee, Waldman v. Canada, Communication No. 694/1996, UN Doc. CCPR/C/67/D/694/1996.

Human Rights Committee, Rakbim Mavlanov and Shansiy Sa'di v. Uzbekistan, Communication No. 1334/2004, UN Doc. CCPR/C/95/D/1334/2004.

Human Rights Committee, Ángela Poma Poma v. Peru, Communication No. 1457/2006, UN Doc. CCPR/C/95/D/1457/2006.

Human Rights Committee, Prince v. South Africa, Communication No. 1474/2006, UN Doc. CCPR/C/91/D/1474/2006.

International Covenant on Civil and Political Rights,19December1966,A/RES/21/2200. International Labour Organization Convention (no. 169) concerning Indigenous and Tribal Peoples in Independent Countries, 27 June 1989, adopted during $76^{\text {th }}$ ILC session. Mexico City Declaration on Cultural Policies, 6 August 1982, adopted during second World Conference on Cultural Policies.

UNESCO Declaration of San Jose, 11 December 1981, UNESCO Doc. FS 82/WF.32 (1982).

UNESCO Universal Declaration on Cultural Diversity, 2 November 2001, Resolution of the $31^{\text {st }}$ General Conference of UNESCO.

United Nations Declaration on the Rights of Indigenous Peoples, 13 September 2007, A/RES/61/295.

\section{SUMMARY}

\section{Cultural Identity in the Case-Law of the Human Rights Committee}

The aim of the article is to present the jurisprudence of the Human Rights Committee on Article 27 of the International Covenant on Civil and Political Rights concerning the rights of persons belonging to ethnic, religious and linguistic minorities. Therefore, the study examines the underprivileged position of minorities within States and focuses on their will to survive as a distinct culture. Examination of the aforementioned caselaw provides an insight into the Committee's understanding of the concept of cultural identity. 
Keywords: cultural identity, cultural rights, rights of minorities, Human Rights Committee

Sylwia Stryjkowska, Adam Mickiewicz University Poznań, Faculty of Law and Administration, Al. Niepodległości 53, 61-714 Poznań, e-mail: sylwia.stryjkowska@amu. edu.pl. 